newborn academy hang onto them should be resisted. What the new set-up needs, preferably at the level of the centre, is what every other industrial society has - an objective merit-based mechanism for making grants of money for research. It is asking too much of an academy whose members are likely to be the chief beneficiaries of what money there is to carry out that task impartially. Nor, as the experience of the past few decades has shown, can resources be shared between productive laboratories without the malign intervention of power-brokers. These laboratories should also go to a new grant-making agency.

What would then be left for the new academy to do? Plenty. As elsewhere, an academy designed to seek out and acknowledge excellence can have a powerful influence on the standards of the research enterprise. To be effective, it must be independent of government, not its agent. Such an academy is also the natural focus for relations with scientific communities elsewhere: there will be a growing need for foreign travel and placement in the years ahead. But the advice of a genuinely independent academy could be especially influential and valuable just now. Russia and the rest of the old union were rightly proud of their accomplishments in science - a triumph of immense talent over appalling difficulties. Most of those who have made the running on economic reform in the past five years have been members of the old academy, and may yet save the old union from catastrophe. Should not the academy stir itself to save a little of its natural science as well?

\section{Dead end tunnel}

The British government has found a clever way of making sure the Channel Tunnel will make no difference.

BRITAIN, forever boasting of its faithful if reluctant compliance with the European Communities' legislation, is furtively but ingeniously planning the most serious crime in the economic lawbooks - an elaborate non-tariff restraint on trade that will entirely out-class the French ploy, some years ago, of sending imported Japanese video-recorders for inspection to a railway siding at Poitiers. That, at least, is the only rational explanation of the arrangements being made (or not made) to connect the British landfall of the Channel Tunnel, due to be opened in 1993, with the rest of the British Isles. Somebody has worked out that there will be no surge in British imports from the mainland if goods sent for sale in Britain are left to rot in Kent, in the southeast corner of England. But Machiavellian to the end, the British government has cleverly disguised its intentions beneath such a laughable facade of muddle that even the French have not yet seen through the trick.

The plot began a decade ago, when the Thatcher government sponsored legislation to allow the tunnel, but on the strict condition that no taxpayers' funds were used either for construction or in arrangements to handle the extra traffic. So far, the British Government is committed only to widening a stretch of the only motorway to the Channel coast which is even now a bottleneck, and whose connection with the rest of Britain is the London Orbital Road, the most congested highway in Europe. But the Channel Tunnel is a railway tunnel (some of whose trains will carry motor-cars) so that rail links with the rest of Britain are all-important. That is where the government's fiendish ingenuity has been concentrated.

First, the nationalized railway, British Rail, was asked to devise a route for a high-speed railway from the Channel towards London, whereupon it became plain that the route would pass through many electorally marginal constituencies whose incumbent MPs support the government. They were quickly up in arms at the environmental nuisance the railway would inflict on their electors; the government decreed that much of the railway should be hidden in tunnels, increasing the estimated cost by more than a half, to $£ 3,600$ million. The idea was that the funds should be raised privately and the railway operated separately from British Rail, which would have been a minor partner in the enterprise.

The government would have known, of course, that such an investment would not happen spontaneously, especially in a recession, but to make assurance doubly sure, it has for years been musing aloud about its hopes for privatizing British Rail, sowing uncertainty in the minds of railway buffs with money enough to fancy playing with full-size trains. To throw off the suspicion that it might not be serious, the government hit on the clever trick of letting BR spend $£ 160$ million buying up houses in suburban southeast London, where its original plan called for a station.

That will not now be needed. In a master-stroke of prevarication, the government has decreed that, if there is ever a high-speed railway, it will follow a different route, crossing to the north bank of the Thames well downstream of London, eventually linking with the rest of the rail network at a grand terminus not yet built (but whose environmental impact, the European Commission complained last week, has been ill-considered). Now the only certainty is further uncertainty. Even if the funds materialize to build the railway, it cannot be finished until a full decade after the opening of the tunnel. During that interval, goods and passengers reaching Britain from the mainland will be fed into a domestic transport system already on the edge of gridlock.

Taken separately, these inconsistencies might be dismissed as incompetence or indecision, which is the cleverness of the plot. Only in combination is their grand design apparent: to keep out imports from the mainland, and all but the most indefatigable of those who live there. Those who believe that what seems to be sheer muddle will make Britain the laughing-stock of Europe should therefore think again, perhaps recalling that when a channel tunnel was first mooted, the British were most of all fearful that it would simply be a way of letting Napoleon's armies walk across. Outwardly, of course, much has changed since then. But who can say that the old xenophobia has entirely been exorcised? 